\title{
ABET accreditation and optics and photonics engineering: an association whose time has come
}

\section{Barry Shoop, Kathleen Robinson}

Barry L. Shoop, Kathleen B. Robinson, "ABET accreditation and optics and photonics engineering: an association whose time has come," Proc. SPIE 8481, Optics Education and Outreach II, 848107 (15 October 2012); doi: 10.1117/12.931263

EDIE Event: SPIE Optical Engineering + Applications, 2012, San Diego, California, United States 


\title{
ABET Accreditation and Optics and Photonics Engineering: An Association Whose Time Has Come
}

\author{
Barry L. Shoop ${ }^{\dagger a}$ and Kathleen B. Robinson ${ }^{b}$ \\ ${ }^{a}$ Department of Electrical Engineering and Computer Science, U.S. Military Academy, West Point, \\ NY 10996; ' 'SPIE, Bellingham, WA 98227
}

\begin{abstract}
The growth and influence of optical and photonics engineering as a discipline warrants increased recognition within both academia and industry. In 2006, SPIE leadership made a strategic decision to pursue membership in ABET, Inc. to lead the profession in the establishment of ABET program criteria for optical and photonics engineering. In 2010, SPIE became a member society of ABET and in 2011 SPIE, in collaboration with our co-lead society IEEE, developed the program criteria for optical and photonics engineering. In this invited presentation we will review the rationale for pursuing ABET accreditation and the benefits of ABET accreditation, discuss the historical context leading to the current state, provide an overview of the process of developing the program specific criteria, and finally describe the way ahead.
\end{abstract} Keywords: ABET, accreditation, program criteria

\section{INTRODUCTION AND HISTORICAL CONTEXT}

ABET is a nonprofit, non-governmental organization that accredits college and university programs in the disciplines of applied science, computing, engineering, and engineering technology. ABET was founded in 1932 as the Engineers' Council for Professional Development (ECPD), an engineering professional body dedicated to the education, accreditation, regulation, and professional development of the engineering professionals and students in the United States. ABET accredits over 3,100 programs at more than 660 colleges and universities in 23 countries. ABET provides specialized, programmatic accreditation that evaluates an individual program of study. ABET is considered the "gold standard" in applied science, computing, engineering and technology accreditation. ABET accreditation, which is voluntary and achieved through a peer review process, provides assurance that a college or university program meets the quality standards established by the profession for which the program prepares its students. ABET accreditation effectively certifies quality in education. ABET is a federation of over 30 professional and technical societies in applied science, computing, engineering, and technology. The Member Societies (1) represent the profession, (2) develop program criteria, (3) appoint Board members, (4) nominate commissioners, and (5) recruit and assign program evaluators.

The journey to formally associate optical and photonics engineering with ABET accreditation began in 2004 with a letter from Professors Charles Joenathan and Robert Bunch from Rose-Hulman Institute of Technology encouraging SPIE to pursue engagement with ABET for the purpose of developing separate accreditation for optical and photonics engineering programs. The phenomenal growth in optics and photonics and the increased need for qualified practitioners suggested that the time had come for the field to stand on its own, as a distinct discipline with a specific set of criteria within ABET. Additionally, the number of existing and emerging optical engineering, optical science and photonics programs across the country are attracting some of the best and brightest students, and these programs clearly need a base of organized standards at the undergraduate education level. Finally, the recognition of optics and photonics as a distinct discipline within ABET is the next logical and critical step toward the advancement of the profession. It should be noted that there existed five optical engineering undergraduate programs that had received ABET accreditation under the General Engineering criteria:

\begin{tabular}{|l|l|c|}
\hline \multicolumn{1}{|c|}{ INSTITUTION } & \multicolumn{1}{c|}{ DEGREE } & YEAR OF FIRST ACCREDITATION \\
\hline University of Alabama at Huntsville & BSE Optical Engineering & 2998 \\
\hline University of Arizona & BS Optical Sciences and Engineering & 2002 \\
\hline University of California, Davis & BS Optical Science and Engineering & 2005 \\
\hline Norfolk State University & BSOE Optical Engineering & 2006 \\
\hline Rose-Hulman Institute of Technology & BS Optical Engineering & 2005 \\
\hline
\end{tabular}

\footnotetext{
${ }^{\dagger}$ Barry.Shoop@usma.edu (O) 845.938.2200
} 
In 2006 SPIE leadership investigated the benefits associated with ABET accreditation and the requirements for becoming a member society. In the same year, the SPIE Board of Directors decided that this course of action was in the best interest of the profession and directed that SPIE apply for membership in ABET. In 2007 the application for SPIE to become a member society of ABET was processed and in 2008 the completed application was submitted to ABET. In 2009 SPIE was notified by ABET that the application had been approved by the ABET Board of Directors but still required ratification by ABET's member societies. In 2010, SPIE was informed that ABET's member societies had ratified SPIE as a member society of ABET. At this point, SPIE was designated as the lead society for criteria related to optics and photonics for the Applied Science Accreditation Commission and SPIE was designated as co-lead society with IEEE for criteria related to these fields for both the Engineering Accreditation Commission and the Technology Accreditation Commission. This was a first for ABET - in the past only one society could serve as the lead society. In 2010 the SPIE Board of Directors also elected Professor Barry Shoop from the U.S. Military Academy at West Point as SPIE's first Representative Director to the ABET Board of Directors and Professor Wei Chen from the University of Central Oklahoma as the alternate Representative Director. Additionally SPIE trained six Program Evaluators, and evaluated two programs in optics and photonics engineering.

\section{ABET PROCESSES AND PROCEDURES}

There are nine individual criteria used as the core of determining program accreditation within the Engineering Accreditation Commission (EAC) - the first eight are common to all engineering programs and the last is programspecific - this criterion defines disciplinary differences between programs. The criteria are categorized as [1]:

\section{General Criteria for Baccalaureate Level Programs}

All programs seeking accreditation from the Engineering Accreditation Commission of ABET must demonstrate that they satisfy all of the following General Criteria for Baccalaureate Level Programs.

\section{Criterion 1. Students.}

Student performance must be evaluated. Student progress must be monitored to foster success in attaining student outcomes, thereby enabling graduates to attain program educational objectives. Students must be advised regarding curriculum and career matters.

The program must have and enforce policies for accepting both new and transfer students, awarding appropriate academic credit for courses taken at other institutions, and awarding appropriate academic credit for work in lieu of courses taken at the institution. The program must have and enforce procedures to ensure and document that students who graduate meet all graduation requirements.

\section{Criterion 2. Program Educational Objectives.}

The program must have published program educational objectives that are consistent with the mission of the institution, the needs of the program's various constituencies, and these criteria. There must be a documented and effective process, involving program constituencies, for the periodic review and revision of these program educational objectives.

\section{Criterion 3. Student Outcomes.}

The program must have documented student outcomes that prepare graduates to attain the program educational objectives.

Student outcomes are outcomes (a) through (k) plus any additional outcomes that may be articulated by the program.

(a) an ability to apply knowledge of mathematics, science, and engineering

(b) an ability to design and conduct experiments, as well as to analyze and interpret data

(c) an ability to design a system, component, or process to meet desired needs within realistic constraints such as economic, environmental, social, political, ethical, health and safety, manufacturability, and sustainability 
(d) an ability to function on multidisciplinary teams

(e) an ability to identify, formulate, and solve engineering problems

(f) an understanding of professional and ethical responsibility

(g) an ability to communicate effectively

(h) the broad education necessary to understand the impact of engineering solutions in a global, economic, environmental, and societal context

(i) a recognition of the need for, and an ability to engage in life-long learning

(j) a knowledge of contemporary issues

(k) an ability to use the techniques, skills, and modern engineering tools necessary for engineering practice.

\section{Criterion 4. Continuous Improvement.}

The program must regularly use appropriate, documented processes for assessing and evaluating the extent to which both the program educational objectives and the student outcomes are being attained. The results of these evaluations must be systematically utilized as input for the continuous improvement of the program. Other available information may also be used to assist in the continuous improvement of the program.

\section{Criterion 5. Curriculum.}

The curriculum requirements specify subject areas appropriate to engineering but do not prescribe specific courses. The faculty must ensure that the program curriculum devotes adequate attention and time to each component, consistent with the outcomes and objectives of the program and institution. The professional component must include:

(a) one year of a combination of college level mathematics and basic sciences (some with experimental experience) appropriate to the discipline. Basic sciences are defined as biological, chemical, and physical sciences.

(b) one and one-half years of engineering topics, consisting of engineering sciences and engineering design appropriate to the student's field of study. The engineering sciences have their roots in mathematics and basic sciences but carry knowledge further toward creative application. These studies provide a bridge between mathematics and basic sciences on the one hand and engineering practice on the other. Engineering design is the process of devising a system, component, or process to meet desired needs. It is a decision-making process (often iterative), in which the basic sciences, mathematics, and the engineering sciences are applied to convert resources optimally to meet these stated needs.

(c) a general education component that complements the technical content of the curriculum and is consistent with the program and institution objectives. Students must be prepared for engineering practice through a curriculum culminating in a major design experience based on the knowledge and skills acquired in earlier course work and incorporating appropriate engineering standards and multiple realistic constraints.

One year is the lesser of 32 semester hours (or equivalent) or one-fourth of the total credits required for graduation. 


\section{Criterion 6. Faculty.}

The faculty must be of sufficient number and must have the competencies to cover all of the curricular areas of the program. There must be sufficient faculty to accommodate adequate levels of student-faculty interaction, student advising and counseling, university service activities, professional development, and interactions with industrial and professional practitioners, as well as employers of students.

The program faculty must have appropriate qualifications and must have and demonstrate sufficient authority to ensure the proper guidance of the program and to develop and implement processes for the evaluation, assessment, and continuing improvement of the program, its educational objectives and outcomes. The overall competence of the faculty may be judged by such factors as education, diversity of backgrounds, engineering experience, teaching effectiveness and experience, ability to communicate, enthusiasm for developing more effective programs, level of scholarship, participation in professional societies, and licensure as Professional Engineers.

\section{Criterion 7. Facilities.}

Classrooms, offices, laboratories, and associated equipment must be adequate to support attainment of the student outcomes and to provide an atmosphere conducive to learning. Modern tools, equipment, computing resources, and laboratories appropriate to the program must be available, accessible, and systematically maintained and upgraded to enable students to attain the student outcomes and to support program needs. Students must be provided appropriate guidance regarding the use of the tools, equipment, computing resources, and laboratories available to the program.

The library services and the computing and information infrastructure must be adequate to support the scholarly and professional activities of the students and faculty.

\section{Criterion 8. Institutional Support.}

Institutional support and leadership must be adequate to ensure the quality and continuity of the program.

Resources including institutional services, financial support, and staff (both administrative and technical) provided to the program must be adequate to meet program needs. The resources available to the program must be sufficient to attract, retain, and provide for the continued professional development of a qualified faculty. The resources available to the program must be sufficient to acquire, maintain, and operate infrastructures, facilities, and equipment appropriate for the program, and to provide an environment in which student outcomes can be attained.

\section{General Criteria for Masters Level Programs}

Masters level programs must develop, publish, and periodically review, educational objectives and student outcomes. The criteria for masters level programs are fulfillment of the baccalaureate level general criteria, fulfillment of program criteria appropriate to the masters level specialization area, and one academic year of study beyond the baccalaureate level. The program must demonstrate that graduates have an ability to apply masters level knowledge in a specialized area of engineering related to the program area.

\section{Program Criteria}

Each program must satisfy applicable Program Criteria (if any). Program Criteria provide the specificity needed for interpretation of the baccalaureate level criteria as applicable to a given discipline. Requirements stipulated in the Program Criteria are limited to the areas of curricular topics and faculty qualifications. If a program, by virtue of its title, becomes subject to two or more sets of Program Criteria, then that program must satisfy each set of Program Criteria; however, overlapping requirements need to be satisfied only once. 


\section{DEVELOPMENT OF PROGRAM SPECIFIC CRITERIA}

On Monday, January 24, 2011 a meeting was held at SPIE's Photonics West in San Francisco, CA to begin the process developing ABET draft program criteria for optical and photonics engineering. The objectives of the meeting were to (1) inform ABET accredited programs and potential programs of SPIE's new role in ABET, (2) understand optical and photonic engineering program accreditation needs, (3) solicit input on and begin first-draft of optics and photonics program criteria, (4) solicit volunteers to assist with the development of program-specific criteria, (5) determine who needs to be involved in the process, and to (6) create a timeline, including steps and milestones for proposing optics/photonics criteria to ABET. Participants in this first meeting were:

\begin{tabular}{|c|c|c|c|}
\hline \multicolumn{4}{|c|}{ Kick-OfF Meeting Participants } \\
\hline Barry Shoop $^{\dagger}$ (Lead) & U.S. Military Academy, West Point & Andrew Berger & University of Rochester \\
\hline Carl Maes $^{\ddagger}$ & University of Arizona & Charles Joenathan $^{\dagger}$ & $\begin{array}{l}\text { Rose-Hulman Institute of } \\
\text { Technology }\end{array}$ \\
\hline David Hagan $^{\ddagger}$ & University of Central Florida & Eric Johnson $^{\dagger}$ & University of North Carolina \\
\hline Hector Baldis $^{+}$ & University of California at Davis & Jim Wyant $^{\dagger}$ & University of Arizona \\
\hline Kevin Harding & GE Global Research & Kyo Song & Norfolk State University \\
\hline Patricia Mead $^{\dagger}$ & Norfolk State University & Theodore Bickart & Colorado School of Mines \\
\hline Wayne Knox $^{\dagger}$ & University of Rochester & Wei Chen & University of Central Oklahoma \\
\hline Jannick Rolland $^{\ddagger}$ & University of Rochester & Robert Lindquist $^{\dagger}$ & University of Alabama at Huntsville \\
\hline Bahaa Saleh $^{\dagger}$ & University of Central Florida & Scott Teare ${ }^{\dagger}$ & $\begin{array}{l}\text { New Mexico Institute of Mining and } \\
\text { Technology }\end{array}$ \\
\hline Mike Nofziger & University of Arizona & Ralph James & Past SPIE President \\
\hline Eugene Arthurs & SPIE Executive Director & Kathleen Robinson & SPIE Manager of Education \\
\hline${ }^{7}$ Department Cha & ${ }^{\ddagger}$ Associate Dean & & \\
\hline
\end{tabular}

In February 2011, an Academic Advisory Group was established to begin the formal process of developing the program specific criteria required for optics and photonics engineering. Members of the Academic Advisory Group were predominately from institutions that had received or anticipated applying for ABET accreditation for their optics and photonics programs. Members of the Academic Advisory Group included:

\begin{tabular}{|c|c|c|c|}
\hline \multicolumn{4}{|c|}{ ACADEMIC ADVISORY GROUP } \\
\hline $\begin{array}{l}\text { Odile Liboiron-Ladouceur } \\
\text { (IEEE Rep) }\end{array}$ & McGill University & Hector A. Baldis & University of California at Davis \\
\hline Scott Teare & $\begin{array}{l}\text { New Mexico Institute of Mining } \\
\text { and Technology }\end{array}$ & $\begin{array}{l}\text { David Hagan } \\
\text { Peter Delfyett (IEEE Rep) } \\
\text { Bahaa Saleh }\end{array}$ & $\begin{array}{l}\text { University of Central Florida, } \\
\text { CREOL }\end{array}$ \\
\hline $\begin{array}{l}\text { Patricia Mead } \\
\text { Kyo D. Song }\end{array}$ & Norfolk State University & Wei Chen & University of Central Oklahoma \\
\hline Charles Joenathan & $\begin{array}{l}\text { Rose-Hulman Institute of } \\
\text { Technology }\end{array}$ & Eric Johnson & University of North Carolina \\
\hline Robert G. Lindquist & $\begin{array}{l}\text { University of Alabama at } \\
\text { Huntsville }\end{array}$ & $\begin{array}{l}\text { Andrew Berger } \\
\text { Jannick Roland } \\
\text { Wayne Knox (OSA Rep) } \\
\end{array}$ & $\begin{array}{l}\text { University of Rochester, The } \\
\text { Institute of Optics }\end{array}$ \\
\hline $\begin{array}{l}\text { Carl Maes } \\
\text { Mike Nofziger } \\
\text { Jim Wyant }\end{array}$ & $\begin{array}{l}\text { University of Arizona, Optical } \\
\text { Sciences Center }\end{array}$ & Barry Shoop (Lead) & $\begin{array}{l}\text { U.S. Military Academy at West } \\
\text { Point }\end{array}$ \\
\hline $\begin{array}{l}\text { Theodore A. Bickart } \\
\text { (IEEE Rep) }\end{array}$ & Colorado School of Mines & & \\
\hline
\end{tabular}


Over the next several months, the Academic Advisory Group crafted draft program specific criteria that met the requirements for undergraduate optical engineering graduates. During this process it was determined that photonics engineering was as of yet insufficiently mature to define separate criteria and therefore this was left for the future. After the draft criteria were complete, an Industry Advisory Group was established to gain insights from industry. The Industry Advisory Group members included:

\begin{tabular}{|l|l|l|l|l|}
\hline \multicolumn{2}{|l|}{ INDUSTRY ADVISORY GROUP } \\
\hline John Brock & Northrop-Grumman & Ray Johnson & Lockheed Martin \\
\hline Walt Bosenberg & Coherent & Richard Juergens & Raytheon \\
\hline Leonard Chen & Raytheon & Ken Kaufmann & Hamamatsu \\
\hline Tony DeMaria & Coherent & Ray Morrison & $\begin{array}{l}\text { Associates for Continuing } \\
\text { Education in Technology and } \\
\text { Science }\end{array}$ \\
\hline Robert Edmund & & Edmund Scientific & Melles Griot \\
\hline Kevin Harding (Lead) & GE Global & Jevin Tice & Lockheed Martin \\
\hline Ray Haynes & Northrop-Grumman & Fred VanMilligen & \\
\hline Waguih S. Ishak & Corning & Jeffrey Wilcox & \\
\hline
\end{tabular}

After roughly seven months, the following program criteria were agreed upon by the community:

PROGRAM CRITERIA FOR OPTICAL, PHOTONIC,
AND SIMILARLY NAMED ENGINEERING PROGRAMS
Co-Lead Societies: SPIE - The International Society for Optical Engineering and the IEEE - Institute of Electrical
and Electronics Engineers
These program criteria apply to all engineering programs that include "optical", "photonic", or similar modifiers in
their titles.
Curriculum
The structure of the curriculum must provide both breadth and depth across the range of engineering topics implied
by the title of the program.
The curriculum must prepare students to have knowledge of and appropriate laboratory experience in: geometrical
optics, physical optics, optical materials and optical and/or photonic devices and systems.
The curriculum must prepare students to apply principles of engineering, basic sciences, mathematics (such as
multivariable calculus, differential equations, linear algebra, complex variables, and probability and statistics) to
modeling, analyzing, designing, and realizing optical and/or photonic devices and systems.
Faculty
For primarily design courses, faculty members must be qualified by virtue of design experience as well as subject
matter knowledge.

The final step to complete this portion of the journey to develop the program criteria was to seek the endorsement of the education governing bodies within both SPIE and IEEE. For the IEEE, the Committee on Engineering Accreditation Activities (CEAA) unanimously endorsed the new program criteria on 16 and 17 July 2011, the Accreditation Policy Committee (APC) unanimously endorsed the criteria on 1 October 2011, and the Education Activities Board (EAB) gave the final approval on 19 November 2011. For SPIE, the Education Committee met and endorsed the criteria on 22 August 2011 and the SPIE Board of Directors approved the program criteria on 26 August 2011. On 22 December 2011, a letter co-signed by Eugene Arthurs, SPIE Executive Director and CEO and E. James Prendergast, IEEE Executive Director, was sent to the ABET Engineering Accreditation Commission for their review and to begin the process of approval and implementation. 
These program criteria specific to the disciplines of optics and photonics engineering are currently in the hands of the ABET Engineering Accreditation Commission who will review them at their July 2012 meeting. If the Engineering Accreditation Commission endorses the criteria, they will then be forwarded to the ABET Board of Directors who will consider them at their October 2012 meeting. If the criteria are approved by the ABET Board of Directors they will be posted for a one year review and comment period. If all goes well, the criteria will be approved for adoption at the end of that year (October 2013) and ABET Headquarters will incorporate the Program Criteria for the next review cycle which begins in January of 2014.

\section{SUMMARY}

The growth and influence of optical and photonics engineering as a discipline warrants increased recognition within both academia and industry. A number of existing and emerging optical engineering, optical science and photonics programs across the country are attracting some of the best and brightest students and these programs clearly need a base of organized standards at the undergraduate level. Defining separate and distinct criteria within ABET for optical and photonics engineering signals another step in the maturation of the field and defines it as a separate discipline within the engineering profession.

\section{REFERENCES}

[1] Criteria for Accrediting Engineering Programs, Effective for Reviews During the 2012-2013 Accreditation Cycle, Engineering Accreditation Commission, ABET Inc., 111 Market Place, Suite 1050, Baltimore, MD 21202. 